\author{
Abstracta Iranica \\ Abstracta Iranica Revue bibliographique pour le domaine irano-aryen \\ Volume 32-33 | 2013 \\ Comptes rendus des publications de 2009-2010
}

\title{
Toby Hartnell. Persepolis in regional context
}

\section{Sébastien Gondet}

\section{(2) OpenEdition}

Journals

Édition électronique

URL : http://journals.openedition.org/abstractairanica/41086

DOI : 10.4000/abstractairanica.41086

ISSN : 1961-960X

Éditeur :

CNRS (UMR 7528 Mondes iraniens et indiens), Éditions de l'IFRI

Édition imprimée

Date de publication : 1 décembre 2013

ISSN : 0240-8910

\section{Référence électronique}

Sébastien Gondet, «Toby Hartnell. Persepolis in regional context », Abstracta Iranica [En ligne], Volume 32-33 | 2013, document 169, mis en ligne le 01 juillet 2016, consulté le 05 octobre 2020. URL : http:// journals.openedition.org/abstractairanica/41086 ; DOI : https://doi.org/10.4000/abstractairanica. 41086

Ce document a été généré automatiquement le 5 octobre 2020.

Tous droits réservés 


\title{
Toby Hartnell. Persepolis in regional context
}

\author{
Sébastien Gondet
}

\section{RÉFÉRENCE}

Toby Hartnell. « Persepolis in regional context ». Oriental Institute News and Notes, 205, Spring 2010, p. 15-19.

1 Ces deux articles résument les résultats de prospections dans la plaine de Persépolis visant à mieux comprendre l'évolution de l'exploitation de la région à partir de la période achéménide jusqu'au début de l'ère islamique. Ces travaux se situent dans la continuité des ceux de W. Sumner et de son équipe dans les années 1960-70. Deux secteurs ont été prospectés au nord de Persépolis et un autre au sud. Les sites achéménides sont très rares, sauf le long de la rivière Pulvar, où près de 50 sites présenteraient des indices d'occupation de cette période. Ce résultat est à mettre en relation avec les récentes découvertes effectuées le long du Pulvar, plus en amont dans la vallée du Tang-e Bulaghi (Abs. Ir. 29, c.r. $n^{\circ} 36$ et 67 et ici $n^{\circ}$ 38). La vallée du Pulvar, qui reliait les deux sites royaux de Pasargades et Persépolis, aurait été occupée à l'achéménide par de petites installations rurales. Dans les deux autres secteurs, les sites sont en majorité sassanides et islamiques. Si au nord-ouest de la plaine, des indices d'occupation pré-achéménide ont été relevés, au sud l'exploitation du territoire se développe seulement entre l'époque sassanide et les débuts de l'ère islamique. D'après les AA., le modèle d'occupation de la plaine aurait évolué entre l'achéménide, où les sites sont sur les pentes des reliefs, vers une installation dans la plaine à l'époque sassanide, permise par l'existence de vastes réseaux d'irrigation et marquée par de nombreux sites hiérarchisés. Cette hypothèse de restitution ne tient pas compte des réseaux de canaux de l'époque achéménide, alimentés par le Kur, l'autre rivière qui arrose la plaine. Leur existence tend à prouver que la plaine, au moins dans sa partie nord, était exploitée à l'époque achéménide, mais il est possible que les preuves de 
cette exploitation aient en grande partie disparu du fait des graves transformations récentes du paysage.

2 [Ce texte concerne également le $\mathbf{n}^{\circ} 168$ ]

\section{AUTEURS}

SÉBASTIEN GONDET

Université Lyon 2 